\title{
KEBIJAKAN PENGENTASAN KEMISKINAN DI KOTA BATAM MELALUI PENDIDIKAN GUNA MEMPERCEPAT PENCAPAIAN MDG's
}

\author{
Diah Ayu Pratiwi \\ Ilmu Pemerintahan Fakultas Ilmu Sosial dan Ilmu Politik \\ Universitas Riau Kepulauan \\ diah_mahdan@yahoo.co.id
}

\begin{abstract}
The development of human capital through education is one of the requirements for the creation of poverty reduction. During the development of education in Batam has been done efforts development and relevance of education in accordance with the development goals of science and technology and the needs of the labor market, with the national education system running and also the target of international commitments in the field of education. However, education development indicators in Batam are still low.

The purpose of this study is to identify poverty and how it relates to education and reduce poverty and accelerate the achievement of the MDGs. The research method used in this research uses qualitative method to explore poverty and education development in Batam. Survey documents relating to educational and psychological development in Batam became an important source of data in this study.

The results of this study indicate that based on the achievement of Gross Participated on Education (APM/APK) and the average years of education in Batam have reached the target according to $M D G$ 's, but the number of illiterates in Batam is still high. Educational development brings with it the inequality of education among various community groups in Batam according to the income they earn.
\end{abstract}

Keywords: development education, poverty, and hinterland

\begin{abstract}
Abstrak
Pembangunan modal manusia melalui pendidikan merupakan salah satu syarat terciptanya penurunan kemiskinan. Selama ini pembangunan bidang pendidikan di Kota Batam telah dilakukan upaya pengembangan dan relevansi pendidikan sesuai dengan tujuan perkembangan IPTEK dan kebutuhan pasar kerja, dengan sistem pendidikan nasional yang berjalan dan juga sasaran komitmen-komitmen internasional dibidang pendidikan. Namun, indicator pembangunan pendidikan di Kota Batam masih rendah.

Tujuan penelitian ini adalah mengidentifikasi kemiskinan dan bagaimana kaitannya antara pembangunan pendidikan dan upaya mengurangi kemiskinan, guna mempercepat pencapaian MDG's. penelitian ini menggunakan metode penelitian kualitatif untuk mengeksplorasi kemiskinan
\end{abstract}


dan pembangunan pendidikan di Kota Batam. Dokumen yang terkait pengembangan pendidikan dan psikologi di Kota Batam menjadi data penting dalam penelitian ini.

Hasil penelitian ini mengindikasikan bahwa pembangunan pendidikan yang didasarkan pada pencapaian APK/APM dan rata-rata lama tahun pendidikan di Kota Batam telah mencapai sasaran menurut MDG's, namun jumlah buta aksara di Kota Batam masih tinggi. Pembangunan pendidikan membawa serta ketimpangan pendidikan diantara berbagai kelompok masyarakat di Kota Batam menurut pendapatan yang mereka peroleh.

Kata Kunci: pembangunan pendidikan, kemiskinan, hinterland

\section{A. Pendahuluan}

Millennium Development Goals (MDG's) merupakan sebuah paradigma pembangunan global yang disepakati secara internasional oleh 189 negara anggota Perserikatan Bangsa-Bangsa (PBB) dalam Konferensi Tingkat Tinggi (KTT) Milenium PBB pada September 2000. Kemudian, Majelis Umum PBB melegalkannya ke dalam Resolusi Majelis Umum PBB No. 55/2 tanggal 18 September 2000 tentang Deklarasi Milenium PBB (A/RES/55/2.United Nations Millennium Declaration). Lahirnya Deklarasi Milenium merupakan bentuk komitmen Negara-negara anggota PBB guna meningkatkan kerjasama global untuk memperbaiki kehidupan sosial ekonomi penduduk dunia. Deklarasi Millenium menempatkan pembangunan manusia sebagai fokus utama pembangunan serta memiliki tenggat waktu dan kemajuan yang terukur. Guna memonitor tingkat pencapaian perbaikan kehidupan sosial penduduk, maka digunakan beberapa yang tertuang dalam 8 target, diantaranya pemberantasan kemiskinan dan kelaparan ekstrem; mewujudkan pendidikan dasar untuk semua; mendorong kesetaraan jender dan pemberdayaan perempuan; menurunkan angka kematian anak; meningkatkan kesehatan ibu; memerangi HIV dan AIDS; malaria serta penyakit lainnya; memastikan kelestarian lingkungan; dan mengembangkan kemitraan global untuk pembangunan. 8 target inilah yang dinamakan sebagai Goals Millennium Development (MDG's)

Indonesia sebagai Negara anggota PBB yang ikut menandatangani Deklarasi Milenium. Pencapaian sasaran MDG's merupakan salah satu prioritas utama bangsa Indonesia. Guna mencapai dan melaksanakan 
indikator-indikator yang tercantum dalam MDG's diperlukan tidak hanya peranan pemerintah pusat tetapi juga peranan pemerintah daerah dalam melakukan perencanaan dan implementasi program pembangunan dari berbagai sektor yang diselenggarakan oleh pemerintah kabupaten/kota.

Dalam pencapaian sasaran MDG's yang menjadi target utama yaitu di bidang pendidikan dan kemiskinan. Kaitan antara pendidikan dan kemiskinan pernah dikemukakan oleh John Stuart Mill dalam teori kependudukan. Secara garis besar Mill menjelaskan bahwa laju pertumbuhan penduduk melampui laju pertumbuhan makanan sebagai suatu aksioma, yang tidak perlu diragukan lagi kebenarannya. Lebih lanjut Mill menjelaskan apabila produktifitas seseorang tinggi maka cenderung mempunyai keluarga yang kecil. Dalam situasi seperti ini fertilitas akan rendah. Tinggi rendahnya fertilitas ditentukan oleh manusia itu sendiri, maka Mill menyarankan untuk meningkatkan tingkat golongan yang tidak mampu yakni dengan meningkatkan kualitas pendidikan penduduk (Malthus, 2007). Secara logika tingkat pendidikan penduduk menentukan sikapnya guna mempertimbangkan perlu tidaknya menambah anak sesuai dengan karir dan usaha yang ada.

Berdasarkan teori tersebut, timbul suatu keyakinan bahwa semakin tingginya laju pertumbuhan penduduk akan berpengaruh terhadap masalah kemiskinan. Apabila tidak ada pembatasan terhadap pertumbuhan penduduk, maka manusia akan mengalami kekurangan bahan makanan. Inilah yang merupakan sumber kemelaratan dan kemiskinan manusia. Kemiskinan merupakan isu terpenting yang perlu mendapat perhatian karena dapat mengancam stabilitas politik dan menyebabkan terjadinya kerusakan terhadap sumber daya alam yang apabila dibiarkan akan menyebabkan kelangkaan sumber daya alam.

Istilah kemiskinan muncul ketika seseorang atau sekelompok orang tidak mampu mencukupi tingkat kemakmuran ekonomi yang dianggap sebagai kebutuhan minimal dari standar hidup tertentu. Kemiskinan bukan hanya berarti rendahnya pendapatan, tetapi juga tidak adanya berbagai faktor lain, misalnya kecukupan pangan, kesehatan, keterlibatan dengan lingkungan sosial, penghargaan penduduk, dan pendidikan yang memadai. Kemiskinan 
juga berarti kehilangan kesempatan untuk mencapai standar kehidupan tertentu lainnya, seperti panjang umur, sehat, bebas dari kelaparan, serta memiliki akses terhadap sarana kesehatan, air bersih, pendidikan, dan sosial. Secara garis besar, kemiskinan merupakan masalah pemenuhan kebutuhan dasar. Sebenarnya, bukan hanya masalah pemenuhan kebutuhan dasar yang dihadapi penduduk Indonesia, namun juga masalah kesenjangan yang mengakibatkan "aset" yang "seharusnya" cukup digunakan oleh seluruh penduduk Indonesia "tidak dapat menjangkau" seluruh lapisan penduduk (Pande, 2010).

Di Indonesia, permasalahan kemiskinan sudah mendapat perhatian luas sejak tahun 1993, dimana pada saat itu Presiden Republik Indonesia berpidato mengenai masalah kemiskinan di depan DPR (BPS, 1999,1). Sejak saat itu, berbagai program untuk mengentas kemiskinan sudah dibuat diantaranya program IDT, JPS, dan berbagai program yang sifatnya memberdayakan penduduk miskin. Namun, kemiskinan tetap saja belum terhapus, bahkan penduduk miskin makin berfluaktif. Berikut ini adalah grafik mengenai tingkat kemiskinan di Indonesia:

\section{Grafik 1.1 Tingkat Kemiskinan di Indonesia}

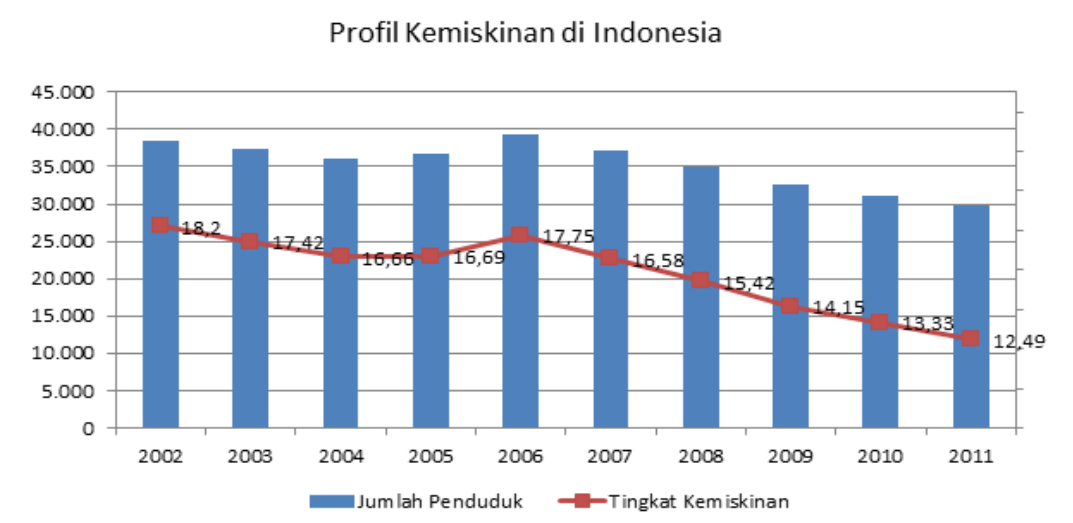

Sumber: Tim Nasional Percepatan dan Penanggulangan Kemiskinan - 2012

Berdasarkan grafik diatas memperlihatkan bahwa pada periode 20022005 terjadi penurunan persentase penduduk miskin dari 18,2 persen pada tahun 2002 menjadi 16,69 persen pada tahun 2005. Namun, pada tahun 2006 terjadi kenaikan jumlah penduduk miskin secara cukup drastis menjadi 17,75 
persen. Pada tahun 2007 - 2011 terjadi penurunan jumlah penduduk miskin dari 16,58 persen menjadi 12,49 persen.

Permasalahan kemiskinan bukan hanya sekadar berapa jumlah dan persentase penduduk miskin. Namun, ada dimensi lain yang perlu diperhatikan yaitu tingkat kedalaman dan keparahan dari kemiskinan tersebut. Selain harus mampu memperkecil jumlah penduduk miskin, kebijakan kemiskinan juga sekaligus dapat mengurangi tingkat kedalaman dan keparahan kemiskinan tersebut. Agar dapat segera keluar dari permasalahan tersebut, diperlukan strategi pembangunan modal manusia yang menempatkan sumberdaya manusia sebagai perspektif pembangunan melalui pendidikan guna memerangi kemiskinan.

Peran pendidikan dalam memerangi kemiskinan sangat menentukan. Negara yang berhasil memerangi kemiskinan merupakan Negara yang mampu memberikan pendidikan kepada warga Negaranya. Pendidikan merupakan condition sine qua non (syarat mutlak) bagi sebuah Negara. Kualitas pendidikan yang melatarbelakangi sumber daya manusia di sebuah Negara menentukan maju mundurnya Negara tersebut. Selain itu, keberhasilan Negara didalam menyediakan pendidikan bagi warga negaranya merupakan kunci sukses bagi Negara dalam mencapai kemakmuran dan kesejahteraan (Zamroni, 2010).

Guna mencapai kemakmuran dan kesejahteraan diperlukan peranan pemerintah terutama dalam meningkatkan pembangunan modal manusia dan mendorong penelitian dan pengembangan agar dapat meningkatkan produktivitas manusia. Peningkatan produktivitas manusia dapat dilakukan melalui investasi pendidikan untuk meningkatkan kualitas sumber daya manusia yang dapat dilihat dari pengetahuan dan keterampilan seseorang. Semakin tinggi tingkat pendidikan seseorang, maka pengetahuan dan keahlian juga akan meningkat, sehingga akan mendorong peningkatan produktivitas kerjanya. Dengan tingkat pendidikan yang tinggi, perusahaan akan memperoleh hasil atau keuntungan yang lebih banyak dengan memperkerjakan tenaga kerja yang memiliki produktivitas tinggi, sehingga perusahaan juga akan bersedia memberikan gaji yang lebih tinggi bagi yang 
bersangkutan. Di sektor informal seperti pertanian, peningkatan ketrampilan dan keahlian tenaga kerjaa mampu meningkatkan hasil pertanian, karena tenaga kerja yang terampil mampu bekerja lebih efisien. Pada akhirnya seseorang yang memiliki produktivitas yang tinggi akan memperoleh kesejahteraan yang lebih baik, yang diperlihatkan melalui peningkatan pendapatan maupun konsumsinya. Rendahnya produktivitas kaum miskin dapat disebabkan oleh rendahnya akses mereka untuk memperoleh pendidikan (Rasidin K dan Bonar M, 2004)

Keterkaitan pendidikan dan kemiskinan sangat besar karena pendidikan memberikan kemampuan untuk berkembang lewat penguasaan ilmu dan keterampilan. Pendidikan menanamkan kesadaran akan pentingnya martabat manusia. Mendidik dan memberikan pengetahuan berarti manggapai masa depan (Criswardani Suryawati, 2005). Dalam penelitian Hemanto Siregar dan Dwi Wahyunuarti (2008) menemukan bahwa pendidikan yang diukur dengan jumlah penduduk yang lulus pendidikan SMP, SMA, dan diploma memiliki pengaruh besar terhadap penurunan jumlah penduduk miskin. Hal ini berarti bahwa pembangunan modal manusia (human capital) melalui pendidikan merupakan determinan penting guna menurunkan jumlah penduduk miskin.

Sampai saat ini, Pemerintah Indonesia belum mampu memberikan hasil yang menggembirakan terkait pengentasan kemiskinan, termasuk Pemerintahan Kepulauan Riau terutama di Kota Batam. Upaya penanggulangan kemiskinan di Kota Batam belum maksimal dilakukan oleh Pemerintah Kota Batam. Berikut ini tingkat kemiskinan penduduk Kepulauan Riau menurut Kabupaten/ Kota pada tahun 2009 - 2010 dapat dilihat secara detail pada tabel 1.2 berikut ini:

\section{Tabel 1.1}

Tingkat Kemiskinan Penduduk di Kepulauan Riau 


\begin{tabular}{|c|c|c|c|c|c|c|}
\hline \multirow[t]{2}{*}{ Daerah } & \multicolumn{2}{|c|}{$\begin{array}{c}\text { Garis Kemiskinan } \\
\text { (Rp/Bulan) }\end{array}$} & \multicolumn{2}{|c|}{$\begin{array}{c}\text { Persentase } \\
\text { Penduduk Miskin } \\
(\%)\end{array}$} & \multicolumn{2}{|c|}{$\begin{array}{c}\text { Jumlah Penduduk } \\
\text { Miskin (Jiwa) }\end{array}$} \\
\hline & 2009 & 2010 & 2009 & 2010 & 2009 & 2010 \\
\hline Karimun & 237250 & 254789 & 6,48 & 7,21 & 15539 & 15344 \\
\hline Bintan & 260143 & 274721 & 7,01 & 7,33 & 9236 & 10428 \\
\hline Natuna & 205825 & 217359 & 4,35 & 4,83 & 43888 & 3348 \\
\hline Lingga & 289115 & 310489 & 16,56 & 15,81 & 15360 & 13626 \\
\hline $\begin{array}{l}\text { Kepulauan } \\
\text { Anambas }\end{array}$ & - & 245079 & - & 4,80 & - & 1797 \\
\hline Kota Batam & 374186 & 401849 & 6,76 & 7,26 & 54777 & 68889 \\
\hline $\begin{array}{l}\text { Kota } \\
\text { Tanjung } \\
\text { Pinang }\end{array}$ & 412718 & 435847 & 13,42 & 12,60 & 26029 & 23640 \\
\hline $\begin{array}{l}\text { Kepulauan } \\
\text { Riau }\end{array}$ & 283965 & 295095 & 8,27 & 8,05 & 125329 & 137072 \\
\hline Indonesia & 200262 & 211726 & 14,15 & 13,33 & $\begin{array}{l}32 . \\
530.000\end{array}$ & $\begin{array}{l}31.023 .39 \\
0\end{array}$ \\
\hline
\end{tabular}

Sumber: Badan Pusat Statistik, 2011 (Berdasarkan hasil Susenas Kor Juli 2010)

Berdasarkan data diatas memperlihatkan bahwa Kota Batam sebagai daerah yang memiliki penduduk miskin terbanyak yaitu berjumlah 54.777 jiwa pada tahun 2009 naik menjadi 68.889 jiwa pada tahun 2010. Kemudian secara berurutan diikuti oleh Kota Tanjung Pinang, Karimun, Lingga, Bintan, Natuna, dan Kepulauan Anambas. Dari data diatas memperlihatkan bahwa usaha Pemerintah Kota Batam dalam menurunkan tingkat kemiskinan belum berhasil.

Pembangunan modal manusia melalui pendidikan merupakan salah satu syarat terciptanya penurunan kemiskinan. Selama ini pembangunan bidang pendidikan di Kota Batam telah dilakukan upaya pengembangan dan relevansi pendidikan sesuai dengan tujuan perkembangan IPTEK dan kebutuhan pasar kerja, dengan sistem pendidikan nasional yang berjalan dan juga sasaran komitmen-komitmen internasional dibidang pendidikan. Pendidikan di Batam saat ini secara umum berjalan sangat baik, hal ini terlihat 
dari Indeks Pembangunan Manusia (IPM) Kota Batam pada periode 2007 2010 dari 76,82 persen meningkat menjadi 77,80 persen. Apabila dibandingkan dengan kabupaten/kota yang ada di Kepulauan Riau, yaitu pada periode 2010 Karimun (75,07 persen), Bintan (74,4 persen), Natuna (70,56 persen), Lingga (71,35 persen), Kepulauan Anambas (68,6 persen), dan Kota Tanjung Pinang (74,59 persen) (BPS, 2010). Berdasarkan data diatas menjadikan Kota Batam yang terbaik di Kepulauan Riau dalam hal kesejahteraan penduduknya.

Meskipun demikian, secara geografis Kota Batam berbentuk pulau, mempunyai 12 kecamatan yang tersebar di pulau-pulau kecil atau yang dikenal dengan nama hinterland. Selama ini, pembangunan pendidikan hanya menitikberatkan di Kota Batam saja. Hal ini tentu saja membawa kendala yang tidak sederhana terutama penduduk yang tinggal di daerah hinterland, misalnya minat untuk mengakses pendidikan, minat untuk melanjutkan pendidikan ke jenjang yang lebih tinggi, putus sekolah, pola perilaku yang akan mengikuti orangtuanya, daya jangkau dan intensitas layanan dan pembinaan oleh para pengelola dan pembina pendidikan.

Selain itu, Kota Batam merupakan salah satu daerah industri terbesar di Indonesia menjadikan Kota Batam sebagai daerah urban yang akan selalu diminati untuk didatangi berbagai ragam penduduk dengan kualifikasi status sosial yang beragam guna mencari pekerjaan. Hal ini berimplikasi terhadap bagaimana melakukan pemerataan kebutuhan layanan penduduk terutama dalam mengakses pendidikan.

Persoalan diatas, memungkinkan tingkat aksesibilitas terhadap pendidikan menjadi rendah. Akses penduduk terhadap fasilitas-fasilitas pendidikan dapat dilihat dari Angka Partisipasi Kasar (APK) dan Angka Partisipasi Murni (APM) yang diestimasi menurut jenjang pendidikan. Pada periode 2007 - 2010, untuk jenjang SD terjadi peningkatan APK dari 102,55 persen pada tahun 2007 menjadi 105,46 persen pada tahun 2010. Pertumbuhan APM meningkat tipis dari 97,14 persen pada tahun 2007 menjadi 97, 65 persen pada tahun 2010. Pada jenjang SLTP, pertumbuhan APK maupun APM mengalami perkembangan yang cukup baik. APK mencapai 95,38 persen dan 
APM 82,34 persen. Jenjang SLTA/SMK terjadi peningkatan APK dari 62,62 persen pada tahun 2007 menjadi 64,12 persen pada tahun 2010. Pertumbuhan APM meningkat tipis dari 58,84 persen pada tahun 2007 menjadi 59,65 persen pada tahun 2010 (BPS Kepri, 2011). Belum tercapainya angka 100 persen pada APK dan APM memperlihatkan belum maksimalnya pembangunan modal manusia melalui pendidikan di Kota Batam.

Tujuan tulisan ini adalah mengidentifikasi kemiskinan dan bagaimana kaitannya antara pembangunan pendidikan dan upaya mengurangi kemiskinan, serta kemana arah dan kebijakan pendidikan yang lebih dapat menjamin pengurangan kemiskinan guna mempercepat pencapaian MDG's. Ruang lingkup tulisan ini adalah penulis akan mengambil jangka waktu pada tahun 2007 - 2010. Tahun-tahun diluar jangkauan penelitian ini akan digunakan penulis untuk memperjelas hubungan antara variabel-variabel yang akan diteliti.

\section{B. Dasar Pemikiran}

Pendidikan dan kemiskinan memiliki hubungan yang positif. Secara makro dapat dijelaskan bahwa semakin tinggi pendidikan semakin baik pekerjaan yang diperoleh, maka semakin tinggi gaji yang diperoleh dan semakin rendah tingkat kemiskinan, dan semakin besar anggaran dapat dibelanjakan untuk pendidikan. Pada dasarnya, pembangunan pendidikan merupakan suatu proses pembangunan ekonomi (Boediono, 1997). Lebih lanjut Boediono menjelaskan apabila ditinjau dari pembangunan ekonomi, pendidikan memiliki dua fungsi. Pertama pendidikan dapat meningkatkan konsumsi, khususnya konsumsi barang-barang teknologi. Kedua, pendidikan memiliki fungsi mempersiapkan tenaga kerja yang berperan dalam proses produksi dan distribusi.

Berdasarkan fungsi pertama, meningkatkan konsumsi akan memperluas pasar dan mendorong tingkat produksi lebih tinggi. Produksi akan menghasilkan pendapatan. Dengan kata lain, semakin tinggi produksi dan semakin tinggi produktivitas akan menghasilkan pendapatan yang semakin tinggi. Sebagian atau seluruh pendapatan akan dipergunakan untuk konsumsi. 
Tingkat pendapatan atau tingkat kemiskinan, secara umum, akan menentukan surplus yang diwujudkan dalam bentuk tabungan. Semakin tinggi pendapatan semakin besar surplus berarti semakin besar jumlah tabungan. Jumlah tabungan merupakan sumber terbentuknya investasi, semakin besar investasi, maka semakin besar kemampuan untuk berproduksi. Investasi dapat dilaksanakan dalam dua bentuk, yaitu investasi fisik dan non fisik. Pada umumnya, human investment dalam bentuk pendidikan dan kesehatan.

Kerangka pikir Boediono diatas, dapat diasumsikan bahwa pendapatan akan mempengaruhi pendidikan melalui dua jalur. Pertama, pendapatan akan menentukan kemampuan berkonsumsi, termasuk konsumsi pendidikan, contohnya sekolah, membayar jasa kursus-kursus, dan sebagainya. Kedua, besarnya pendapatan akan memberikan kemungkinan untuk menyediakan anggaran pendidikan. Semakin tinggi pendapatan memberikan kemungkinan semakin besar anggaran untuk pendidikan.

Pendapatan memberikan kemampuan penduduk untuk berkonsumsi di bidang pendidikan. Namun, pendapatan nasional tidak terbagi secara merata diantara penduduk. Dengan demikian, kemampuan berkonsumsi di bidang pendidikan berbeda diantara penduduk menurut pendapatannya. Penduduk yang termasuk dalam kelompok yang memperoleh pendapatan tinggi akan memiliki kemampuan berkonsumsi di bidang pendidikan lebih besar daripada kelompok yang berpendapatan rendah. Tentu saja, ketimpangan pendapatan akan melahirkan ketimpangan memperoleh pendidikan (Zamroni, 2010).

Berangkat dari pemikiran diatas, dapat diasumsikan bahwa bagi penduduk miskin, kesempatan memperoleh pendidikan dan pendapatan bagaikan lingkaran yang tidak berujung (vicious circle). Penduduk yang miskin sejak awal usia anak hanya mampu menyekolahkan anak-anaknya pada jenjang TK atau SD dengan kualitas yang rendah. Lulusan dari sekolah yang berkualitas rendah hanya mampu mengantarkan para lulusannya masuk ke sekolah yang juga berkualitas rendah. Hal ini dikarenakan dengan masuk kesekolah yang lebih tinggi didasarkan pada nilai yang diperoleh saat ujian sekolah jenjang sebelumnya atau lewat tes masuk. Sehingga, anak-anak dari keluarga miskin akan kesulitan untuk mendapatkan sekolah yang bermutu. 
Dengan demikian, apabila anak-anak keluarga miskin dapat masuk ke perguruan tinggi yang bermutu rendah ataupun hanya dapat masuk ke program studi yang relatif "sepi peminat", hal tersebut tidak menjamin masa depan mereka guna mendapatkan pendapatan yang tinggi. Sebaliknya, orang yang kaya kebanyakan memiliki latarbelakang pendidikan yang relatif lebih tinggi dan memiliki kesempatan untuk menyekolahkan anak-anak sejak TK di sekolah yang bermutu. Hal ini akan memberikan jaminan bagi anak-anak mereka untuk masuk ke jenjang sekolah yang lebih tinggi dan bermutu, dan pada akhirnya mengantarkan anak-anak mereka memasuki kampus pilihan dan/atau program-program studi yang memungkinkan lulusannya mendapatkan pekerjaan dengan pendapatan yang lebih tinggi.

Vicious circle ini memiliki makna bahwa sekolah merupakan proses yang disebut social reproduction. Lewat proses pendidikan, kelompok orang kaya akan melahirkan keturunan yang berpendidikan dan kaya juga. Dan sebaliknya, kelompok orang-orang miskin akan melahirkan keturunan yang juga miskin dan berpendidikan relatif rendah.

\section{Pembangunan Pendidikan Di Kota Batam}

Pencapaian pendidikan dapat dilihat dari Angka Partisipasi Kasar (APK) atau Partisipasi Murni (APM), selain itu juga dari persentase buta huruf dan lama tahun bersekolah. APK dan APM diestimasi berdasarkan pada jenjang pendidikan. APK SD adalah jumlah siswa SD dibagi dengan jumlah penduduk usia SD (7-12 tahun), APK SLTP adalah jumlah siswa SLTP dibagi dengan jumlah penduduk usia SLTP (13-15 tahun), APK SLTA adalah jumlah siswa SLTA dibagi dengan jumlah anak usia SLTA (16-18 tahun), dan APK Perguruan Tinggi adalah mahasiswa dibagi dengan jumlah penduduk usia PT (19-24 tahun). Sedangkan APM SD adalah siswa dalam usia SD (7-12 tahun) dibagi dengan total anak usia SD, APM SLTP adalah siswa dalam usia SLTP (13-15 tahun) dibagi dengan total anak usia SLTP, APK SLTA adalah siswa dalam usia SLTA (16-18 tahun) dibagi dengan total anak usia SLTA, dan APK PT adalah mahasiswa dalam usia 19-24 tahun dibagi dengan total penduduk usia 19-24 tahun (BPS, 2011). 
Menurut MDG's bahwa tercapainya pendidikan dasar dengan Gross Enrollment Rate (GER) atau Angka Partisipasi Kasar (APK) pada angka 90\%. Di Batam, APK untuk jenjang pendidikan SD sudah mencapai diatas 100\% sejak tahun 2006. Berikut ini tabel yang menjelaskan tentang Angka Partisipasi Kasar dan Angka Partisipasi Murni Di Kota Batam pada periode 2007/2008 - 2010/2011 (tabel 1.3 dan 1.4):

\section{Tabel 3.1}

Perkembangan Angka Partisipasi Kasar (APK) periode 2007/2008 2010/2011

\begin{tabular}{|ccccccc|}
\hline $\begin{array}{c}\text { Tingkat } \\
\text { Pendidikan }\end{array}$ & $2005 /$ & $2006 /$ & $2007 /$ & $2008 /$ & $2009 /$ & $2010 /$ \\
\hline \multicolumn{1}{c}{$(\mathbf{1})$} & $(2)$ & $(3)$ & $(4)$ & $(5)$ & $(6)$ & $(7)$ \\
\hline 1. SD/MI & 94.00 & 100.9 & 102.5 & 105.2 & 105.5 & 109.4 \\
\hline $\begin{array}{l}\text { 2. SLTP/ } \\
\text { MTs }\end{array}$ & 79.95 & 89.12 & 91.31 & 93.26 & 95.38 & 97.50 \\
\hline $\begin{array}{l}\text { 3. SLTA/ } \\
\text { MA }\end{array}$ & 59.10 & 61.44 & 62.62 & 63.91 & 64.12 & 65.25 \\
\hline
\end{tabular}

Sumber: Batam Dalam Angka 2011, Pemerintah Kota Batam Tahun 2011

Berdasarkan pada tabel diatas memperlihatkan bahwa pada periode 2005/2006 APK SD Kota Batam sudah mencapai 90\%, sesuai dengan target pencapaian MDG's. Kemudian pada periode 2006/2007 - 2010/2011 APK SD Kota Batam sudah mencapai diatas 100\%. Peningkatan APK SD Kota Batam tidak diikuti oleh APK SLTP dan SLTA yang masih dibawah 100\%. Meskipun APK Kota Batam berdasarkan tingkat pendidikan semakin tahun semakin meningkat, namun tidak begitu signifikan peningkatannya.

Tabel 3.2

Perkembangan Angka Partisipasi Murni (APM) periode 2007/2008 2010/2011

\begin{tabular}{|ccccccc|}
\hline Tingkat & $2005 /$ & $2006 /$ & $2007 /$ & $2008 /$ & $2009 /$ & $2010 /$ \\
Pendidikan & 2006 & 2007 & 2008 & 2009 & 2010 & 2011 \\
\hline$(1)$ & $(2)$ & $(3)$ & $(4)$ & $(5)$ & $(6)$ & $(7)$ \\
\hline
\end{tabular}




\begin{tabular}{|lllllll|}
\hline 1. SD/MI & 94.00 & 100.9 & 97.14 & 97.25 & 97.65 & 98.68 \\
\hline 2. SLTP/ MTs & 79.95 & 89.12 & 76.08 & 81.70 & 82.34 & 84.35 \\
\hline 3. SLTA/ MA & 59.10 & 61.44 & 58.84 & 59.31 & 59.65 & 59.75 \\
\hline
\end{tabular}

Sumber: Batam Dalam Angka 2011, Pemerintah Kota Batam Tahun 2011

Tabel 1.4 menunjukkan bahwa pada jenjang SD, pertumbuhan APM di Kota Batam selama lima tahun terakhir mengalami pasang surut menunjukkan pertumbuhan yang tidak berarti. Hal ini antara lain, karena angka drop out jenjang SD masih cukup tingi, khususnya untuk kelas-kelas awal dan didaerah hinterland. Pada jenjang SLTP/MTs, APM menunjukkan perkembangan yang cukup baik, dimana APK mencapai 84 persen. Namun untuk mencapai program wajib belajar 9 tahun bukan merupakan tugas yang mudah, mengingat hampir sebagian besar sasaran berada pada daerah-daerah yang sulit dicapai terutama di daerah hinterland.

Pada jenjang SLTA/ MA menunjukkan pertumbuhan APM selama lima tahun terakhir mengalami stagnasi, meskipun pada periode 2006/2007 mengalami peningkatan namun pada periode 2007/2008 mengalami penurunan. Permasalahan ini hampir sama pada jenjang SLTP/MTs, dimana sebagian besar sasaran berada pada daerah yang secara geografis sulit dicapai terutama di daerah hinterland.

Selain indikator APK dan APM dalam melihat pencapain pendidikan, berapa lama tahun rata-rata penduduk Kota Batam mendapatkan pendidikan pendidikan formal. Pada tabel 1.5 menyajikan informasi mengenai rata-rata lama sekolah berdasarkan jenjang pendidikan dan kelas pada periode 2006 2010.

Tabel 3.3

Rata-rata Lama Bersekolah Tahun 2007 - 2010

\begin{tabular}{|lcccc|}
\hline Uraian & 2007 & 2008 & 2009 & 2010 \\
\hline Rata-rata & 10.7 & 10.7 & 10.4 & 10.9 \\
Lama & & & & \\
Bersekolah & & & & \\
\hline
\end{tabular}

Sumber: RPJMD Kota Batam 2010 - 2015

Jika dilihat pada tabel 3.3 diatas rata-rata lama bersekolah di Kota Batam mengalami peningkatan meskipun tidak signifikan. Adapun rata-rata 
lama sekolah sebesar 10.9 tahun mengandung pengertian bahwa rata-rata penduduk Kota Batam mengeyam pendidikan selama hampir 11 tahun, atau hingga kelas 2 SLTA.

Tabel 3.4

Jumlah Lulusan Menurut Tingkat Pendidikan Tahun 2009 - 2010

\begin{tabular}{|lcccccccc|} 
& \multicolumn{2}{c}{ SD } & \multicolumn{2}{c}{ SLTP } & \multicolumn{2}{c}{ SLTA } & \multicolumn{2}{c|}{ SMK } \\
Uraian & $\begin{array}{c}\text { Jumlah } \\
\text { Siswa }\end{array}$ & $\begin{array}{c}\text { Jumlah } \\
\text { Lulusan }\end{array}$ & $\begin{array}{c}\text { Jumlah } \\
\text { Siswa }\end{array}$ & $\begin{array}{c}\text { Jumlah } \\
\text { Lulusan }\end{array}$ & $\begin{array}{c}\text { Jumlah } \\
\text { Siswa }\end{array}$ & $\begin{array}{c}\text { Jumlah } \\
\text { Lulusan }\end{array}$ & $\begin{array}{c}\text { Jumlah } \\
\text { Siswa }\end{array}$ & $\begin{array}{c}\text { Jumlah } \\
\text { Lulusan }\end{array}$ \\
\hline $\begin{array}{l}\text { Jumlah } \\
\text { Lulusan }\end{array}$ & 10.090 & 10.056 & 7.731 & 7.709 & 2.954 & 2.936 & 2.116 & 2.113 \\
\hline
\end{tabular}

Sumber: RPJMD Kota Batam 2010 - 2015

Berdasarkan tabel 3.4 tidak menunjukkan angka 100 persen penduduk Kota Batam lulus berdasarkan tingkat pendidikan. Hal ini antara lain, karena angka droup out penduduk Batam pada jenjang SD, SLTP, dan SLTA cukup tinggi meskipun tidak signifikan.

Sementara itu, jumlah penduduk Kota Batam yang mengalami buta aksara masih banyak terutama di daerah hinterland. Hal ini dapat dilihat pada tabel 3.5 mengenai jumlah buta huruf/ buta aksara penduduk Kota Batam tahun $2010-2011$.

Tabel 3.5

Jumlah Buta Huruf/ Buta Aksara Kota Batam Tahun 2010 - 2011

\begin{tabular}{ccccc}
\hline Tahun & $\begin{array}{c}\text { Jumlah } \\
\text { Penduduk }\end{array}$ & $\begin{array}{c}\text { Tidak/ Belum } \\
\text { Pernah Sekolah }\end{array}$ & $\begin{array}{c}\text { Jenjang } \\
\text { Umur }\end{array}$ & $\begin{array}{c}\text { Buta Huruf/ } \\
\text { Buta Aksara }\end{array}$ \\
\hline $\mathbf{2 0 1 0}$ & 1.056 .701 & 115.522 & $15-24$ & 909 \\
$\mathbf{2 0 1 1}$ & 1.137 .894 & 98.140 & $15-24$ & 1057 \\
\hline
\end{tabular}

Sumber: Dinas Pendidikan Kota Batam

Tabel 3.5 memperlihatkan bahwa jumlah buta huruf/ buta aksara masih banyak terjadi di Kota Batam. Buta aksara merupakan salah satu momok yang menakutkan dalam pembangunan pendidikan dan berpengaruh terhadap Pembangunan Indeks Manusia. Masih besarnya angka buta aksara yang terdapat di Kota Batam, mengindikasikan tingkat partisipasi pendidikan penduduk Kota Batam masih rendah. 


\section{Kesenjangan Pendidikan dan Kemiskinan}

Pada umumnya pendapatan keluarga mencerminkan status sosial ekonomi suatu keluarga, hal ini sangat berpengaruh terhadap keberhasilan pendidikan seseorang yang pada gilirannya akan mempengaruhi pekerjaan yang diperoleh. Kemampuan keluarga dalam menyekolahkan anaknya ke jenjang SD tidak terlalu pengaruh terhadap pendapatan yang dimiliki. Hal ini dikarenakan pemerintah memberikan pendidikan gratis kepada penduduk Indonesia pada jenjang Sekolah Dasar.

Berdasarkan APM Kota Batam tahun 2007 - 2010, jenjang pendidikan SD semua kelompok pendapatan dari 20 persen pendapatan terendah sampai 20 persen pendapatan tertinggi dapat menyekolahkan anaknya. APM dari lima kelompok pendapatan memiliki posisi APM yang sama pada skitar 90. Hal ini berarti bahwa program pemerintah Wajib Belajar 6 tahun sudah tercapai.

Namun, pada jenjang pendidikan SLTP dan SLTA menunjukkan pola yang berbeda. Penduduk 20 persen terkaya memiliki APM yang paling tinggi, diikuti oleh kelompok 20 persen terkaya kedua sampai kelompok paling miskin memiliki APM terendah. Pada jenjang SLTA, APM kelompok 20 persen terkaya tahun 2010 mengalami peningkatan, semakin menjauhi APM kelompok yang lain. Sehingga, kelompok penduduk yang lebih kaya memiliki kesempatan akses pendidikan yang lebih besar dibandingan kelompok lain. Dengan demikian, kelompok dari keluarga paling kaya meiliki akses yang besar dalam menyekolahkan anaknya sampai jenjang SLTA hingga Perguruan Tinggi dengan kualitas pendidikan yang terjamin. Berbeda halnya dengan kelompok keluarga paling miskin, memiliki kesulitan dalam akses pendidikan ke jenjang SLTA. Karena pada umunya SLTA baik negeri maupun swasta yang ada di Kota Batam berada pada kecamatan-kecamatan besar sehingga bagi sebagian penduduk untuk sekolah SLTA, diperlukan biaya transportasi yang cukup besar terutama penduduk yang berada di daerah hinterland. Berikut tabel 4.1 Jumlah Sekolah yang ada di Kota Batam Tahun 2010.

\section{Tabel 4.1}

Jumlah Sekolah di Kota Batam Berdasarkan Kecamatan tahun 2010 


\begin{tabular}{|c|c|c|c|c|c|c|c|c|}
\hline \multirow[t]{2}{*}{ Kecamatan } & \multicolumn{2}{|c|}{ TK } & \multicolumn{2}{|c|}{ SD } & \multicolumn{2}{|c|}{ SLTP/MTs } & \multicolumn{2}{|c|}{$\begin{array}{c}\text { SLTA/SMK/ } \\
\text { MA }\end{array}$} \\
\hline & Negeri & Swasta & Negeri & Swasta & Negeri & Swasta & Negeri & Swasta \\
\hline $\begin{array}{l}\text { Belakang } \\
\text { Padang }\end{array}$ & - & 3 & 14 & 2 & 6 & 2 & 2 & 1 \\
\hline $\begin{array}{l}\text { Batu } \\
\text { Ampar }\end{array}$ & 1 & 26 & 4 & 8 & 1 & 5 & 1 & 2 \\
\hline Sekupang & 2 & 38 & 11 & 18 & 3 & 9 & 2 & 3 \\
\hline Nongsa & & 22 & 10 & 11 & 4 & 6 & 1 & 2 \\
\hline Bulang & 2 & 1 & 11 & 1 & 3 & 3 & 1 & 1 \\
\hline $\begin{array}{l}\text { Lubuk } \\
\text { Baja }\end{array}$ & 1 & 27 & 9 & 11 & 1 & 8 & 1 & 6 \\
\hline Sei Beduk & 1 & 30 & 6 & 13 & 2 & 5 & 1 & 2 \\
\hline Galang & 1 & - & 24 & 1 & 7 & 1 & 3 & - \\
\hline Bengkong & 1 & 36 & 13 & 14 & 3 & 9 & 1 & 4 \\
\hline $\begin{array}{l}\text { Batam } \\
\text { Kota }\end{array}$ & 1 & 69 & 10 & 32 & 7 & 12 & 1 & 7 \\
\hline Sagulung & 1 & 65 & 17 & 26 & 8 & 6 & 1 & 2 \\
\hline Batu Aji & 1 & 44 & 7 & 22 & 3 & 7 & 1 & 6 \\
\hline Total & 12 & 361 & 136 & 159 & 48 & 73 & 17 & 36 \\
\hline
\end{tabular}

Sumber: Batam Dalam Angka 2011

Jika melihat tabel 4.1 menjelaskan bahwa jumlah sekolah di Kota Batam lebih banyak berada pada daerah mainland (Kecamatan Batu Ampar, Sekupang, Nongsa, Lubuk Baja, Sei Beduk, Bengkong, Batam Kota, dan Batu Aji) dibandingkan dengan di daerah hinterland (Kecamatan Belakang Padang, Bulang dan Galang). Hal ini memperjelas disparitas pendidikan antara penduduk kaya dan miskin dalam memperoleh akses pendidikan dengan kualitas mutu terjamin.

\section{E. Penutup}

Pada masa Orde Baru, ada tiga strategi utama dalam kebijakan pendidikan yang bertumpu pada: pemerataan pendidikan, peningkatan kualitas, dan peningkatan manajemen pendidikan. Namun, gaya bahasa dan 
ornamen dapat berubah sesuai dengan selera penentu kebijakan yang pada intinya tidak pernah bergeser dari pemerataan, mutu dan manajemen.

Berangkat dari uraian diatas, pembangunan pendidikan yang didasarkan pada pencapaian APK/APM dan rata-rata lama tahun pendidikan di Kota Batam telah mencapai sasaran menurut MDG's, namun jumlah buta aksara di Kota Batam masih tinggi. Pembangunan pendidikan membawa serta ketimpangan pendidikan diantara berbagai kelompok masyarakat di Kota Batam menurut pendapatan yang mereka peroleh. Penduduk yang termasuk kelompok 20 persen berpendapatan tinggi memperoleh kesempatan pendidikan yang jauh lebih besar dibandingkan dengan penduduk kelompok 20 persen berpendapatan rendah. Gambaran diatas baru dalam aspek kuantitas, namun pada aspek kualitas tidak akan jauh berbeda.

Berangkat dari asumsi diatas, kebijakan pendidikan selama ini memperkuat teori mengenai pendidikan merupakan awal proses stratifikasi sosial yang berakhir pada social reproduction. Hal ini berakibat pada pernyataan "yang kaya semakin kaya dan yang miskin semakin miskin" merupakan kenyataan sebagai dari hasil proses pendidikan. Hanya masyarakat yang memiliki pendapatan yang lebih besarlah yang dapat menikmati akses pendidikan yang lebih tinggi. Dengan kata lain, sesungguhnya pendidikan menegaskan adanya kemiskinan lintas generasi. Setidak-tidaknya pendidikan tidak dapat berbuat banyak menghadapinya.

Guna memerangi kemiskinan melalui pendidikan, Pemerintah Kota Batam perlu merumuskan beberapa kebijakan. Pertama, perlu adanya pemerataan jumlah sekolah baik jenjang SD - SLTA di Kota Batam terutama di daerah hinterland dan kemudahan akses dalam hal ini transportasi untuk menjangkau sekolah tersebut. Kedua, Pemerintah Kota Batam khususnya Dinas Pendidikan perlu menggalakkan program Buta Aksara dan pentingnya pendidikan pada masyarakat terutama masyarakat yang berada di daerah hinterland.

Ketiga, perlu dirumuskan kebijakan non konvensional melalui pendidikan nonformal di Kota Batam. Kebijakan ini mengembalikan makna pendidikan sesungguhnya yang memiliki prinsip bahwa pendidikan bukan 
sekedar sekolah atau pendidikan formal, yang menekankan pada penguasaan ilmu pengetahuan dan teknologi. Penguasaan terhadap ilmu pengetahuan dan teknologi, para peserta didik tercabut dari akar budaya sosial masyarakatnya. Apa yang dipelajari tidak ada kaitannya dengan realitas kehidupan mereka. Pendidikan nonformal yang akan langsung memberikan kemampuan dan fasilitas kepada peserta didik untuk dapat belajar dan bekerja. Sehingga mereka dapat belajar dan bekerja berdasarkan pada potensi yang dimiliki masing-masing peserta didik. Dengan demikian mereka dapat keluar dari kemiskinan dengan usaha atau potensi yang mereka miliki.

\section{Daftar Pusataka}

Criswardani, Suryawati. 2005. Memahami Kemiskinan Secara Multidimensional. Dapat diakses di http://www.jmpkonline.net/Volume 8/Vol_08 No_03_2005.pdf. diunduh tanggal 14 Februari 2013. 
Kutanegara, Pande Made. 2010. Penanggulangan Kemiskinan di Era Otonomi Daerah: Dilema Peran Pemerintah dan Masyarakat. Yogyakarta: Pusat Studi Kebijakan dan Kependudukan UGM.

Malthus, et. al. 2007. Kependudukan Dilema dan Solusi. Bandung: Nuansa.

Pemerintah Kota Batam. 2011. Batam Dalam Angka 2011. Batam

Pemerintah Kota Batam. 2015. Laporan RPJMD Kota Batam Tahun 2010 2015. Batam

Siregar, Hermanto dan Dwi Wahyuniarti. 2008. "Dampak Pertumbuhan Ekonomi Terhadap Penurunan Jumlah Penduduk Miskin". http://pse.litbang.deptan.go.id/ind/pdffiles/PROS_2008_MAK3.pdf. Diunduh pada tanggal 20 Februari 2013.

Sitepu, Rasidin K. dan Bonar M. Sinaga. 2004. Dampak Investasi Sumber Daya Manusia Terhadap Pertumbuhan Ekonomi dan Kemiskinan di Indonesia: Pendekatan Model Computable General Equilibrium. http://ejournal.unud.ac.id/?module=detailpenelitian\&idf $=7 \& i d j=48 \&$ $i d v=18 \& i d i=48 \& i d r=191$. Diunduh tanggal 20 Februari 2013.

Zamroni. 2010. Pendidikan dan Kemiskinan. Yogyakarta: Pusat Studi Kebijakan dan Kependudukan UGM. 